\title{
The usefulness of molecular diagnosis in the assessment of the aetiology, clinical phenotypes and risk of food-induced anaphylaxis in children
}

\author{
'Allergology and Pulmonology Department, Institute of Tuberculosis and Lung Diseases, Regional Branch in Rabka-Zdrój, Rabka-Zdrój, Poland \\ 2 Department of Pathophysiology, Medical College of Rzeszów University, Rzeszów, Poland \\ ${ }^{3}$ Paediatric and Allergology Department, Specialist Hospital, Jasło, Poland \\ ${ }^{4}$ Department of Paediatric Pneumonology, Department of Paediatrics No. 3, Medical University of Lodz, Łódź, Poland \\ Correspondence: Łukasz Błażowski, Allergology and Pulmonology Department, Institute of Tuberculosis and Lung Diseases, Regional Branch in Rabka-Zdrój, Prof. Jana Rudnika 3B, 34-700 Rabka-Zdrój, Poland, \\ e-mail: I.blazowski@gmail.com
}

\begin{abstract}
Aim: Food-induced anaphylaxis is most common in the paediatric population and has an unpredictable course. The aim of this paper was to perform a demographic and clinical assessment of food-induced anaphylaxis in children using molecular diagnosis. Materials and methods: The study included 541 children aged 0-18 years who developed 893 sudden reactions to food. Levels of IgEs against 112 allergen molecules were measured in each child. We analysed demographic and clinical data in two age groups. The aetiology of anaphylaxis was determined at the level of source allergens and at the level of allergen molecules. We also determined the risk factors for severe clinical course of reactions. Results: A total of 631 food-induced anaphylactic reactions developed by 421 children were included in the analysis. The group of children aged $0-6$ years was mostly composed of boys $(p=0.0023)$ and children with atopic dermatitis $(p=0.0001)$. Also, cutaneous and mucosal symptoms were more common $(p<0.0001)$, and milk casein, Bos d 8, was the most common cause of anaphylaxis in this group $(p<0.0001)$. In the group of $7-18$-year-olds, anaphylaxis was more common in children with no asthma or atopic dermatitis $(p=0.0001)$; hazelnuts $(p=0.0005)$ and, in terms of allergen molecules, walnut $2 \mathrm{~S}$ albumin, Jug $\mathrm{r} 1(p=0.0011)$, were a more common cause of reaction; as well as exercise-induced anaphylaxis $(p<0.0001)$ and cardiovascular symptoms $(p=0.0247)$ were more common. In the study population, more severe anaphylaxis was more common in children without asthma or atopic dermatitis $(p=0.0428)$ and in the case of anaphylaxis induced by cashew nut $2 S$ albumin, Ana o $3(p<0.0001)$ and wheat allergen, Tri a $14(p=0.0143)$. Conclusions: Molecular diagnostics allows for a detailed assessment of the aetiology and the risk of severe food-induced anaphylaxis.
\end{abstract}

Keywords: food-induced anaphylaxis, children, epidemiology, allergen molecules

Cel pracy: Anafilaksja związana z pokarmem występuje najczęściej w populacji dziecięcej, a jej przebieg jest nieprzewidywalny. Celem opracowania była analiza demograficzna i kliniczna anafilaksji indukowanej przez pokarm u dzieci z wykorzystaniem metod diagnostyki molekularnej. Materiał i metoda: Badaniem objęto 541 dzieci w wieku 0-18 lat, u których wystąpiły 893 reakcje natychmiastowe na pokarm. U każdego dziecka oznaczono stężenie IgE w stosunku do 112 molekuł alergenowych. Przeprowadzono analizę danych demograficznych i klinicznych w dwóch grupach wiekowych. Określono etiologię anafilaksji na poziomie alergenów źródłowych oraz na poziomie molekuł alergenowych. Określono też czynniki ryzyka ciężkiego przebiegu klinicznego reakcji. Wyniki: Do analizy włączono 631 reakcji anafilaktycznych na pokarm, które wystąpiły u 421 dzieci. W grupie dzieci w wieku 0-6 lat większość stanowili chłopcy ( $p=0,0023)$ oraz dzieci z atopowym zapaleniem skóry $(p=0,0001)$, częściej obserwowano objawy ze strony skóry i błon śluzowych ( $p<0,0001)$, a najczęstszą przyczyną anafilaksji była kazeina mleka, Bos d $8(p<0,0001)$. W grupie dzieci w wieku 7-18 lat anafilaksja była częstsza u dzieci bez astmy i atopowego zapalenia skóry $(p=0,0001)$, częściej przyczyną reakcji były orzechy laskowe ( $p=0,0005)$, a w zakresie molekuł alergenowych $2 S$ albumina orzecha włoskiego, Jug $\mathrm{r} 1$ $(p=0,0011)$, częściej obserwowano anafilaksję indukowaną wysiłkiem $(p<0,0001)$ oraz częściej występowały objawy ze strony układu sercowo-naczyniowego $(p=0,0247)$. W badanej populacji cięższy przebieg anafilaksji był częstszy u dzieci bez astmy i atopowego zapalenia skóry $(p=0,0428)$ oraz w przypadku anafilaksji wywołanej przez $2 S$ albuminę orzecha nerkowca, Ana o 3 $(p<0,0001)$ i alergen pszenicy, Tri a $14(p=0,0143)$. Wnioski: Diagnostyka molekularna pozwala na szczegółową ocenę etiologii oraz ryzyka ciężkiego przebiegu anafilaksji związanej z pokarmem. 


\section{INTRODUCTION}

$\mathrm{F}$ ood hypersensitivity affects $6.8 \%$ of children $\leq 10$ years of age ${ }^{(1)}$, whereas food-induced anaphylaxis (FIA), which is the most common type of anaphylaxis in the paediatric population, affects 1 in 5,000 chil$\mathrm{dren}^{(2)}$. Anaphylaxis is an unpredictable, potentially fatal reaction. Infants, small children and adolescents are at the highest risk of FIA ${ }^{(2)}$. The incidence of FIA in the population of Polish children is unknown; only a preliminary epidemiological study on the aetiology of anaphylaxis in children under 3 years of age has been published so $\mathrm{far}^{(3)}$. The development of molecular diagnosis in allergology (component resolved diagnostics, CRD) has made it possible to assess the aetiology of anaphylaxis at the level of an allergenic molecule containing an epitope capable of binding to an allergen-specific class $\mathrm{E}$ immunoglobulin $\operatorname{IgE}(\operatorname{asIgE})^{(4)}$. CRD also allows to assess the risk of anaphylaxis induced by a specific allergen molecule, as well as to determine the severity of a potential FIA episode ${ }^{(4)}$. The aim of this study was to perform a demographic and clinical assessment of the study population, with a comparative analysis in specific age groups, to determine the aetiology of anaphylaxis at the level of allergen source and allergen molecules, as well as to identify clinical phenotypes associated with the risk of severe FIA based on the occurrence and clinical picture of food-induced anaphylaxis in a large, homogeneous population of children aged $0-18$ years.

\section{MATERIALS AND METHODS}

\section{Study design}

The study included 541 children aged $0-18$ years treated for food-induced acute allergic reactions at the Allergology and Pulmonology Department, Institute of Tuberculosis and Lung Diseases in Rabka-Zdrój in the period from March 29, 2012 to December 31, 2020. We analysed medical records covering 893 episodes of sudden food-induced reactions. The diagnosis of systemic allergic reaction or food-induced anaphylaxis was based on a detailed medical history and clinical picture, closely correlated with the food consumed, according to the definitions presented below, which are based on the criteria of the National Institute of Allergy and Infectious Disease and the Food Allergy and Anaphylaxis Network ${ }^{(5)}$, the World Allergy Organization Anaphylaxis Committee ${ }^{(2)}$ and the Australasian Society of Clinical Immunology and Allergy ${ }^{(6)}$. The severity of anaphylaxis was graded based on the 4-grade Mueller's scale ${ }^{(7)}$. The lack of correlation between symptoms and food intake was an exclusion criterion.

Medical data was collected and analysed by two independent researchers, including one expert in anaphylaxis, who entered the data into an electronic database. The analysis included demographic data, coexisting atopic diseases, the nature and sequence of clinical symptoms, the type, origin and dose of food that induced anaphylaxis, the presence of anaphylaxis cofactors, as well as the treatment used and its outcomes.

Detailed allergy diagnosis, including skin prick tests with standard extracts of food and inhaled allergens, using a positive control in the form of a $10 \mathrm{mg} / \mathrm{mL}$ histamine solution, was performed in each child in accordance with the applicable guidelines ${ }^{(8)}$. Blood samples were collected from all children on day 1 of hospital stay to measure serum levels of allergen-specific IgE (asIgE) antibodies against native allergen extracts and allergen molecules using standard procedures. For this purpose, we used the singleplex ImmunoCAP ${ }^{\text {ix }} 100$ System (Thermo Fisher Scientific, Uppsala, Sweden) and the ImmunoCAP ISAC ${ }^{\mathrm{m}} 112$ for Multiplex Allergen Testing (Thermo Fisher Scientific, Uppsala, Sweden), following the manufacturer's instructions described in our previous paper ${ }^{(9)}$. In the case of disagreement on the causal allergen, prick-to-prick tests with foods according to guidelines were performed $^{(8)}$.

\section{Definitions}

\section{Food-induced anaphylaxis (FIA)}

A rapid-onset disease developing after exposure to a food allergen and manifested by: (i) cutaneous and/or mucosal involvement (generalised urticaria, flushing, pruritus, angioedema), and involvement of at least one of the following systems: respiratory (dyspnoea, bronchospasm, pharyngeal/laryngeal oedema) and/or cardiovascular system (hypotension, dysfunctions caused by reduced central nervous system perfusion) and/or the gastrointestinal tract (persistent vomiting and/or severe abdominal cramping) and/or (ii) any sudden drop in blood pressure and/or sudden lower and/or upper airway obstruction following exposure to a food allergen, regardless of the presence of skin symptoms ${ }^{(2,5,6)}$.

\section{Systemic allergic reaction (SAR)}

Mild, slowly progressing reaction limited to one system, with cutaneous/mucosal (urticaria, mild angioedema, erythema, pruritus), gastrointestinal (itching of the mouth, nausea, drooling) or upper respiratory tract (mild nasal symptoms, itching of the throat) involvement ${ }^{(10)}$.

\section{Coexisting atopic diseases}

Asthma and its severity were diagnosed based on the Global Initiative for Asthma (GINA) guidelines ${ }^{(11)}$. Atopic dermatitis (AD) was diagnosed based on physical examination, including an assessment of its severity using the SCORAD questionnaire $^{(12)}$.

\section{Allergen}

An allergen molecule expressing an epitope, which is recognised by an allergen-specific IgE, on its surface ${ }^{(4)}$. 


\section{Data analysis}

In the first stage, an analysis of (i) demographic and clinical data of the study population, (ii) the course of anaphylactic reactions and (iii) the aetiology of anaphylaxis at the level of both allergen source and allergen molecule was performed. In the second stage, the above analyses were performed separately for two age groups: 0-6-year-olds and 7-18-year-olds, and the results were compared using statistical methods to identify significant differences between the individual parameters. This was followed by data analysis for factors likely to contribute to the severity of food-induced anaphylaxis.

\section{Statistical analysis}

Continuous variables were presented using the median with a quartile range, nominal and categorized variables (using the number and percentage of observations). Nominal or categorised variables were compared between clinically defined subgroups using Fisher's exact two-way test or the chi-square test. The null hypothesis was rejected at $p<0.05$. TIBCO Software Inc. (2017) and Statistica (data analysis software system), version 13 , were used for statistical processing.

\section{RESULTS}

\section{Demographic and clinical characteristics of the study population}

As a result of detailed verification, 631 food-induced anaphylactic reactions in 421 children were included in the analysis. The criteria for anaphylaxis were not met for 262 episodes, and were classified as mild systemic allergic reactions (SARs). Of all reactions, 148 (23.5\%) events were observed in the first year of life, 254 ( $40.3 \%)$ by the age of 2 years, 348 (55.2\%) by the age of 3 years, and 488 (77.3\%) by the age of 6 years (Fig. 1).
The demographic and clinical characteristics of the study population is shown in Tab. 1 . Boys were twice more likely to develop anaphylaxis (67.2\%), and $17.8 \%$ of children did not have any atopic diseases. There were 29 (4.6\%) cases of food-dependent exercise-induced anaphylaxis (FDEIA), and 7 biphasic episodes (1.1\%). Adrenaline was used in 52 (8.2\%) reactions. A total of 87 (13.8\%) episodes were qualified as Mueller's grade 4 reactions.

\section{Aetiology of anaphylaxis}

Figs. $2 \mathrm{~A}$ and $\mathrm{B}$ show the aetiology of FIA in children aged $0-18$ years by allergenic sources and allergen molecules (allergens), respectively. The most common sources of FIAinducing allergens in this population included cow's milk proteins $(21.1 \%)$, egg white $(14.9 \%)$ and peanuts (14.9\%). The most common allergen molecules included milk casein - Bos d 8 (14.3\%), ovomucoid (found in egg white) - Gal d 1 (13.3\%), and peanut $2 \mathrm{~S}$ albumin - Ara h 2 (11.4\%).

Figs. 3 A, B and C show FIA aetiology by allergen sources in different age groups. The most common causes of anaphylaxis in children $\leq 1$ year of age included cow's milk proteins ( $n=66)$, followed by egg white $(n=43)$, wheat $(n=13)$, and peanuts $(n=12)$. Milk proteins $(n=124)$ were the most common source of FIA-inducing allergens in children $\leq 5$ years of age, whereas peanuts $(n=28)$, followed by hazelnuts $(n=21)$ were the most common allergen sources in children $>5$ years of age.

\section{Comparison of children aged 0-6 years and $7-18$ years}

Due to the significantly higher prevalence of FIA in children $\leq 6$ years of age (Fig. 1), we compared the demographic and clinical characteristics and the aetiology of anaphylaxis between the population of children $\leq 6$ years of age (infancy

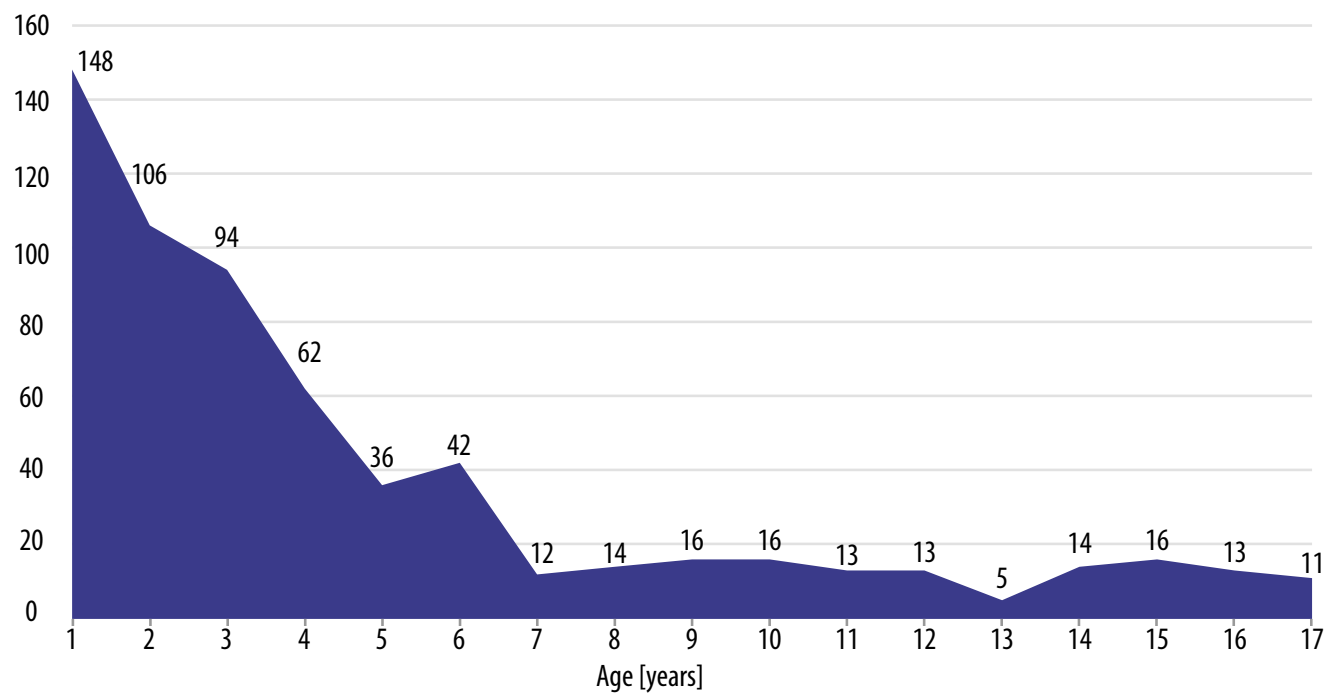

Fig. 1. The incidence of food-induced anaphylaxis in the population of children aged 0-18 years by years of life. Data are presented as numerical values. Own elaboration 
and preschool) and the children aged 7 to 18 years (school period and adolescents) (Tabs. 2-4, Figs. 4 A, B and 5 A, B). In the group of younger children ( $0-6$ years), boys accounted for the vast majority ( $71 \%$ vs. $50 \%$; $p=0.0023), \mathrm{AD}$ symptoms without asthma were dominant (33.3\% vs. $10.5 \%$; $p=0.0001$ ), and the most common causes of anaphylaxis included milk ( $26 \%$ vs. $4.2 \% ; p<0.0001)$ and egg proteins (18.2\% vs. $3.5 \%$; $p<0.0001)$, and, at the level of allergen molecules, casein (Bos d 8) (17.4\% vs. $3.5 \%$; $p<0.0001)$, ovomucoid (Gal d 1) (16.2\% vs. 3.5\%; $p<0.0001)$ and alpha-lactalbumin (Bos d 4) (6.6\% vs. 0.7\%; $p=0.0014)$. In the group of older children (7-18 years), patients diagnosed with asthma without $\operatorname{AD}$ (36.9\% vs. $22.6 \%$; $p=0.0128)$ and children without other atopic diseases $(34.2 \%$ vs. $14.2 \%$; $p=0.0001)$ accounted for the majority. FDEIA was significantly more common $(17.5 \%$ vs. $0.8 \% ; p<0.0001)$ and adrenaline was used more frequently $(14.7 \%$ vs. $6.4 \%$; $p=0.0025)$. Furthermore, hazelnuts $(12.6 \%$ vs. $3.7 \%$; $p=0.0005)$, walnuts $(8.4 \%$ vs. $2.1 \%$; $p=0.0017)$ and peach (3.5\% vs. $0.6 \% ; p=0.0230)$, and, at the level of allergen molecules, walnut $2 \mathrm{~S}$ albumin - Jug $\mathrm{r} 1$ (7\% vs. $1.2 \% ; p=0.0011)$, PR-10 family hazelnut protein Cor a $1(4.9 \%$ vs. $0.2 \% ; p=0.0003)$ and peach lipid transfer

A
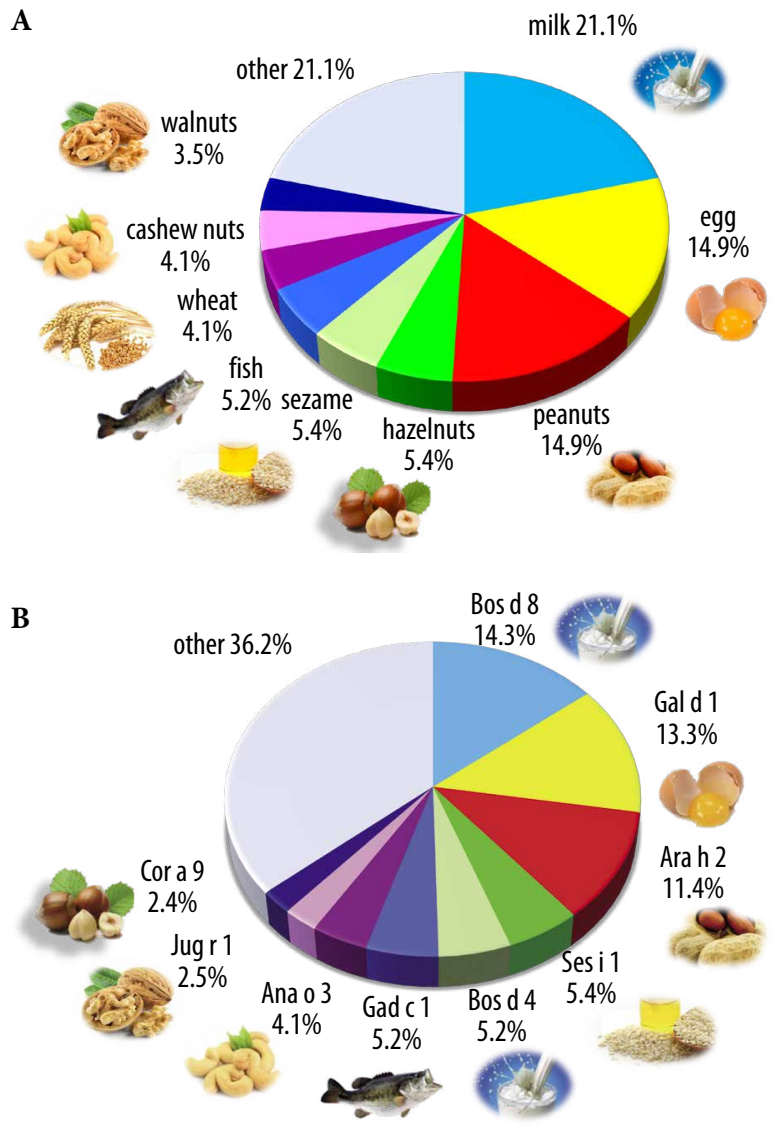

Fig. 2. Aetiology of 631 cases of food-induced anaphylaxis in children aged 0-18 years; A. incidence by allergenic sources; B. incidence by allergen molecules (allergens). Data are presented as percentage values (\%). Own elaboration

\begin{tabular}{|c|c|c|}
\hline \multirow{2}{*}{$\begin{array}{c}\text { Age (years), median } \\
\text { (quartile range) }\end{array}$} & \multicolumn{2}{|c|}{$3(2-6)$} \\
\hline & $n$ & $\%$ \\
\hline \multicolumn{3}{|l|}{ Sex } \\
\hline - female & 138 & 32.8 \\
\hline - male & 283 & 67.2 \\
\hline \multicolumn{3}{|l|}{ Comorbidities } \\
\hline - AD (no asthma) & 123 & 29.2 \\
\hline - asthma (no AD) & 106 & 25.2 \\
\hline - AD + asthma & 117 & 27.8 \\
\hline - no asthma, no AD & 75 & 17.8 \\
\hline \multicolumn{3}{|l|}{ Other data } \\
\hline - FDEIA & 29 & 4.6 \\
\hline - biphasic & 7 & 1.1 \\
\hline - adrenaline injection & 52 & 8.2 \\
\hline \multicolumn{3}{|l|}{ Grade (Mueller, 1966) $^{(7)}$} \\
\hline 1 & 16 & 2.5 \\
\hline 2 & 344 & 54.5 \\
\hline 3 & 184 & 29.2 \\
\hline 4 & 87 & 13.8 \\
\hline \multicolumn{3}{|c|}{ AD - atopic dermatitis; FDEIA - food-dependent exercise-induced anaphylaxis. } \\
\hline
\end{tabular}

Tab. 1. Demographic and clinical characteristics of the study population $(\mathrm{n}=421)$ and food-induced anaphylactic reactions $(\mathrm{n}=631)$. Own elaboration

\begin{tabular}{|c|c|c|c|c|c|}
\hline \multirow{2}{*}{ Characteristic } & \multicolumn{2}{|c|}{$0-6$ years } & \multicolumn{2}{|c|}{$7-18$ years } & \multirow{2}{*}{$p\left(\right.$ chi $\left.^{2}\right)$} \\
\hline & $n$ & $\%$ & $n$ & $\%$ & \\
\hline \multicolumn{5}{|l|}{ Sex } & 0.0023 \\
\hline - female & 100 & 29.0 & 38 & 50 & \\
\hline - male & 245 & 71.0 & 38 & 50 & \\
\hline \multicolumn{6}{|l|}{ Comorbidities } \\
\hline - AD (no asthma) & 115 & 33.3 & 8 & 10.5 & 0.0001 \\
\hline - asthma (no AD) & 78 & 22.6 & 28 & 36.9 & 0.0128 \\
\hline - AD + asthma & 103 & 29.9 & 14 & 18.4 & 0.0479 \\
\hline - no asthma, no AD & 49 & 14.2 & 26 & 34.2 & 0.0001 \\
\hline \multicolumn{6}{|l|}{ Other } \\
\hline - FDEIA & 4 & 0.8 & 25 & 17.5 & $<0.0001$ \\
\hline - biphasic & 6 & 1.2 & 1 & 0.7 & 0.9375 \\
\hline - adrenaline injection & 31 & 6.4 & 21 & 14.7 & 0.0025 \\
\hline \multicolumn{5}{|c|}{ Grade (Mueller, 1966) ${ }^{(7)}$} & 0.0572 \\
\hline 1 & 11 & 2.2 & 5 & 3.5 & \\
\hline 2 & 279 & 57.2 & 65 & 45.4 & \\
\hline 3 & 138 & 28.3 & 46 & 32.2 & \\
\hline 4 & 60 & 12.3 & 27 & 18.9 & \\
\hline \multicolumn{6}{|c|}{ AD - atopic dermatitis; FDEIA - food-dependent exercise-induced anaphylaxis. } \\
\hline
\end{tabular}

Tab. 2. Comparison of the demographic and clinical characteristics of the population of children aged 0-6 years (345 children, 488 reactions) and 7-18 years (76 children, 143 reactions). Own elaboration 


\begin{tabular}{|c|c|c|c|c|c|}
\hline \multirow{2}{*}{ Source allergen } & \multicolumn{2}{|c|}{$0-6$ years } & \multicolumn{2}{|c|}{$7-18$ years } & \multirow{2}{*}{$p\left(\right.$ chi $\left.^{2}\right)$} \\
\hline & $n$ & $\%$ & $n$ & $\%$ & \\
\hline Cow's milk & 127 & 26.0 & 6 & 4.2 & $<0.0001$ \\
\hline Egg white & 89 & 18.2 & 5 & 3.5 & $<0.0001$ \\
\hline Peanuts & 76 & 15.6 & 18 & 12.6 & 0.2387 \\
\hline Sezame & 28 & 5.7 & 6 & 4.2 & 0.4164 \\
\hline Fish & 26 & 5.3 & 7 & 4.9 & 0.8351 \\
\hline Wheat & 23 & 4.7 & 3 & 2.1 & 0.1605 \\
\hline Cashew nuts & 20 & 4.1 & 6 & 4.2 & 1 \\
\hline Hezelnuts & 18 & 3.7 & 18 & 12.6 & 0.0005 \\
\hline Kiwi & 12 & 2.5 & 5 & 3.5 & 0.5737 \\
\hline Walnuts & 10 & 2.1 & 12 & 8.4 & 0.0017 \\
\hline Apple & 10 & 2.1 & 6 & 4.2 & 0.2360 \\
\hline Peach & 3 & 0.6 & 5 & 3.5 & 0.0230 \\
\hline
\end{tabular}

Tab. 3. Comparison of anaphylaxis aetiology by the most common source allergens between children aged 0-6 years (488 reactions) and 7-18 years (143 reactions). Own elaboration
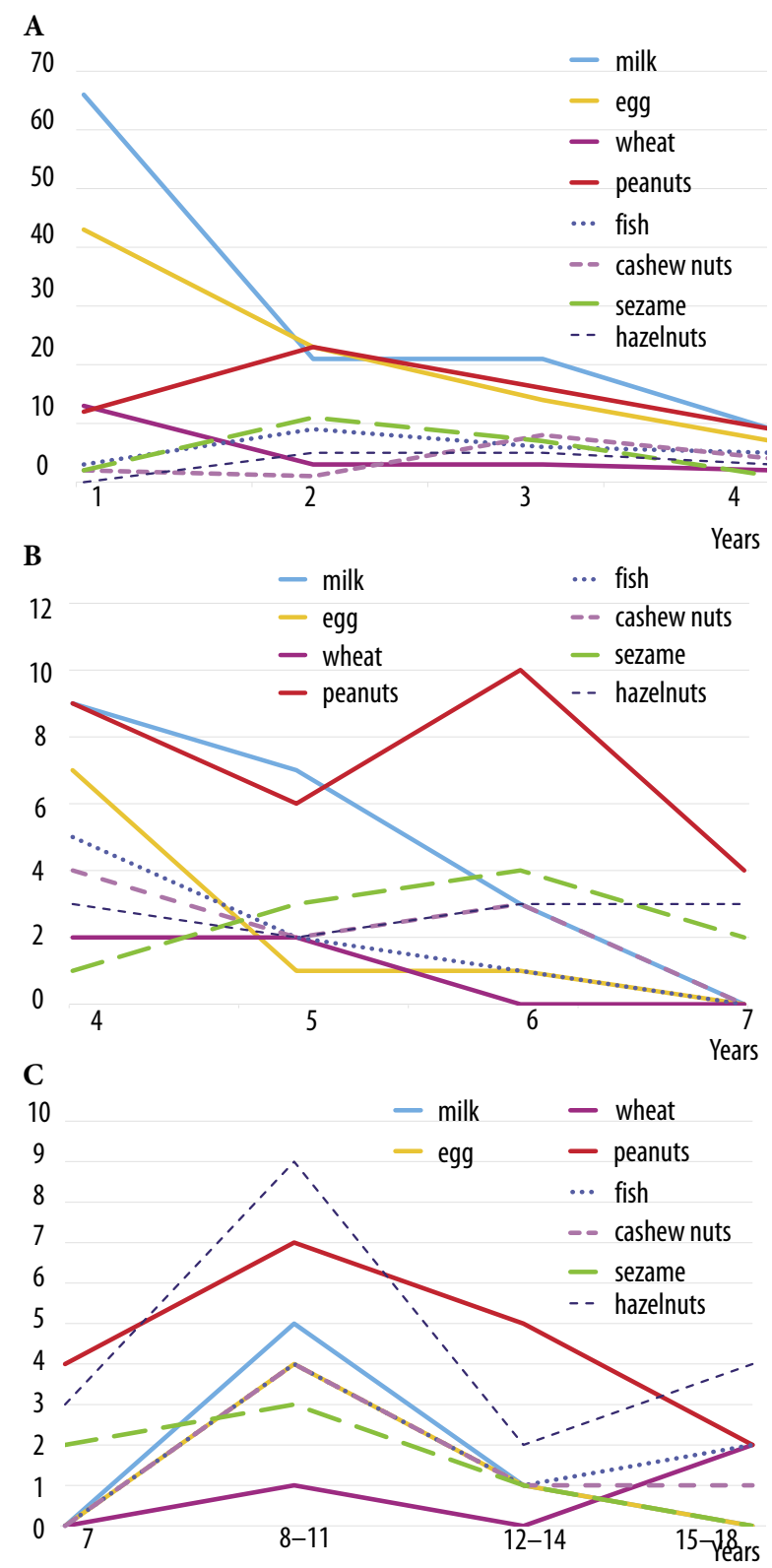

Fig. 3. Aetiology of anaphylaxis by allergenic sources and age; A. age 0-4 years; B. age 4-7 years old; C. age 7-18 years. Data are presented as numerical values. Own elaboration protein (LTP) - Pru p 3 (2.1\% vs. $0.2 \%$; $p=0.0458)$ were a significantly more common cause of FIA. Anaphylactic reactions to hazelnuts and peanuts were the most common causes of FIA in this age group, but there was no significant difference in the incidence compared to children aged 0-6 years ( $12.6 \%$ vs. $15.6 \%$; $p=0.2387$ ) (Tab. 3$)$, similar to the main peanut allergen, $2 \mathrm{~S}$ albumin, Ara h 2 (7.7\% vs. $12.5 \%$; $p=0.0770$ ) (Tab. 4).

In the group of children aged 0-6 years, the most common symptoms of anaphylaxis involved the skin and mucous membranes and were observed significantly more often in this group than in children over 6 years of age $(82.2 \%$ vs. $67.1 \% ; p<0.0001$ ) (Tab. 5, Fig. 6). In the group of children aged 7-18 years, the most common symptoms were related to the respiratory system $(81.1 \%)$, and, compared to children under 6 years of age, older children were significantly more likely to develop cardiovascular symptoms $(18.9 \%$ vs. $11.5 \% ; p=0.0247)$.

\section{Factors influencing the severity of the clinical course of anaphylaxis}

\section{Age}

Compared to younger children ( $0-6$ years of age), the most severe, grade 4, anaphylaxis was more common (close to the threshold of statistical significance) in older children aged $7-18$ years $(18.9 \%$ vs. $12.3 \% ; p=0.0572)$ (Tab. 2$)$.

\section{Atopic diseases}

Compared to children with asthma and AD, children who did not have asthma and AD were more likely to develop more severe anaphylaxis (grade 3 and 4 ) (35.9\% vs. 50.7\%, respectively; $p=0.0428$ ) (Tab. 6, Fig. 7). On the other hand, mild anaphylaxis was significantly more common in children with asthma and $\mathrm{AD}(64.1 \%$ vs. $49.3 \%$; $p=0.0428)$.

\section{Anaphylaxis-inducing allergens}

Allergen sources (i) that significantly more often induced severe grade 3 and 4 reactions included cashew nuts $(80.8 \%$, $p<0.0001)$ and, at the level of allergenic molecules (ii), cashew nut $2 \mathrm{~S}$ albumin - Ana o $3(80.8 \%, p<0.0001)$ and 


\begin{tabular}{|c|c|c|c|c|c|}
\hline \multirow{2}{*}{ Allergen } & \multicolumn{2}{|c|}{ 0-6 years } & \multicolumn{2}{|c|}{$7-18$ years } & \multirow{2}{*}{$p\left(\right.$ chi $\left.^{2}\right)$} \\
\hline & $n$ & $\%$ & $n$ & $\%$ & \\
\hline Bos d 8 & 85 & 17.4 & 5 & 3.5 & $<0.0001$ \\
\hline Gal d 1 & 79 & 16.2 & 5 & 3.5 & $<0.0001$ \\
\hline Arah 2 & 61 & 12.5 & 11 & 7.7 & 0.0770 \\
\hline Bos d 4 & 32 & 6.6 & 1 & 0.7 & 0.0014 \\
\hline Ses i 1 & 28 & 5.7 & 6 & 4.2 & 0.4164 \\
\hline Gad c1 & 26 & 5.3 & 7 & 4.9 & 0.8351 \\
\hline Ana 03 & 20 & 4.1 & 6 & 4.2 & 1 \\
\hline Tri a 19 & 13 & 2.7 & 1 & 0.7 & 0.2057 \\
\hline Cora 9 & 12 & 2.5 & 3 & 2.1 & 1 \\
\hline Act d 1 & 10 & 2.1 & 3 & 2.1 & 1 \\
\hline Mald 1 & 10 & 2.1 & 4 & 2.8 & 0.7526 \\
\hline Juar1 & 6 & 12 & 10 & 70 & 0.0011 \\
\hline Cora 1 & 1 & 0.2 & 7 & 4.9 & 0.0003 \\
\hline Cor a 14 & 5 & 1.0 & 4 & 2.8 & 0.2304 \\
\hline Prup 3 & 1 & 0.2 & 3 & 2.1 & 0.0458 \\
\hline
\end{tabular}

Tab. 4. Comparison of anaphylaxis aetiology by the most common allergen molecules between children aged 0-6 years (488 reactions) and 7-18 years (143 reactions). Own elaboration

\begin{tabular}{|c|c|c|c|c|c|}
\hline \multirow{2}{*}{ System } & \multicolumn{2}{|c|}{$0-6$ years } & \multicolumn{2}{|c|}{$7-18$ years } & \multirow[b]{2}{*}{$p$} \\
\hline & $n$ & $\%$ & $n$ & $\%$ & \\
\hline Skin and mucous mambranes & 404 & 82.2 & 96 & 67.1 & $<0.0001$ \\
\hline Gastrointestinal & 222 & 45.5 & 70 & 49.0 & 0.5047 \\
\hline Respiratory & 369 & 75.6 & 116 & 81.1 & 0.1781 \\
\hline Central nervous system & 84 & 17.2 & 29 & 20.3 & 0.3884 \\
\hline Cardiovascular & 56 & 11.5 & 27 & 18.9 & 0.0247 \\
\hline
\end{tabular}

Tab. 5. Comparison of the incidence of symptoms from different systems during 488 anaphylaxis reactions in 0-6-year olds and 143 reactions of anaphylaxis in 7-18-year olds. Own elaboration

wheat LTP protein - Tri a $14(71.4 \%, p=0.0143)$ (Tabs. 7 and 8 , Figs. 8 and 9). Allergens that significantly more often induced mild grade 1 and 2 reactions were, (i) at the level of allergen source, egg white $(69.2 \%, p=0.0127)$, and, (ii) at the level of allergen molecules, ovomucoid (Gal d 1) (70.2\%, $p=0.0091)$.

\section{DISCUSSION}

We analysed epidemiological data, clinical picture and risk factors for severe food-induced anaphylaxis based on 631 reactions in a homogeneous population of 421 Polish children aged 0-18 years. All children were diagnosed with the allergen responsible for anaphylaxis at the allergen molecule level (CRD). Significant age-related differences were found for many of the parameters tested. Compared to schoolage children, the majority of 0-6-year-olds were boys and children with AD; cow's milk proteins and casein (Bos d 8) were the most common causes of FIA, and skin/mucosal involvement was more common in this group. Compared to younger children, anaphylaxis was more common in children without atopic diseases, hazelnuts, and, at the level of allergen molecule, walnut $2 \mathrm{~S}$ albumin (Jug $\mathrm{r}$ 1) were a more common cause of the reaction, and FDEIA and cardiovascular symptoms were also more frequent in the group of 7-18-year-olds. Identification of clinical phenotypes with a higher risk of severe was an important finding in our study. Grades 3 and 4 were significantly more common in children without any atopic diseases, as well as in patients with anaphylaxis caused by cashew nut $2 \mathrm{~S}$ albumin, Ana o 3, and also by Tri a 14, a wheat flour lipid transfer protein (LTP) allergen.

This study is a comprehensive epidemiological and clinical assessment of food-induced anaphylaxis in a large population of Polish children. So far, only preliminary data have been available, based on a survey conducted in a group of 305 Polish allergologists, in which the incidence of food-induced anaphylaxis was estimated at $29.8 \%$ of all (297 cases) hypersensitivity reactions, without distinguishing between the age of patients or the allergenic source ${ }^{(13)}$. Furthermore, partial epidemiological studies on the aetiology of 133 FIA cases in 0-3-year-olds were published in $2018^{(3)}$. Our study showed that the most common causes of anaphylaxis in 0-18-year-olds were cow's milk proteins (21.1\%) and egg white (14.9\%); however, seeds, which include tree nuts, legumes, cereal grains and true seeds, were the largest group (46.9\%), which corresponds to Miles et al. ${ }^{(14)}$. The dominance of seeds as the cause of anaphylaxis is evident from the age of 2 years, as shown in Figs. 3 A, 3 B and 3 C. These figures show the aetiology of the FIA in each year of children's life for eight source allergens that were most likely to induce anaphylaxis in the study population.

The use of molecular diagnostics to assess the allergen trigger at the molecular level is an important value of our study. Apart from our studies ${ }^{(9)}$, only two other studies using CRD to determine food allergens in very small groups of FIA patients have been published so far $^{(15,16)}$. We showed in this study that the most common allergen triggers for 631 

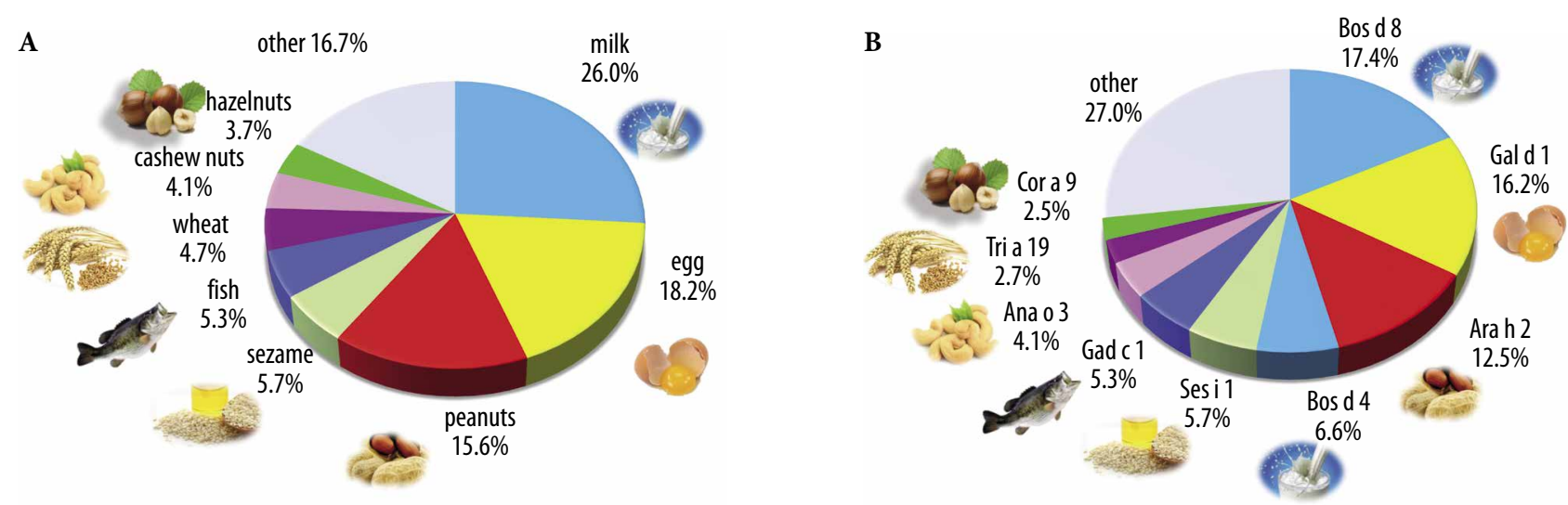

Fig. 4. Aetiology of 488 cases of food-induced anaphylaxis in 345 children aged 0-6 years; A. by allergenic sources; B. by allergen molecules (allergens). Own elaboration

A

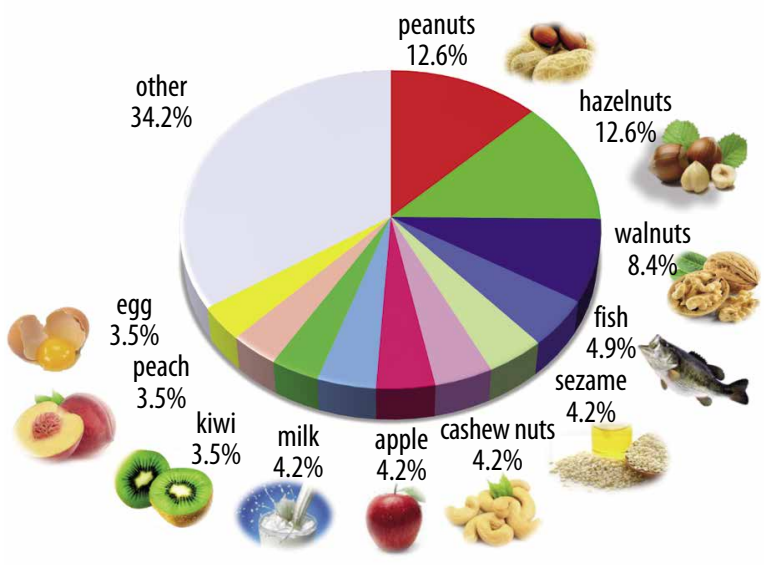

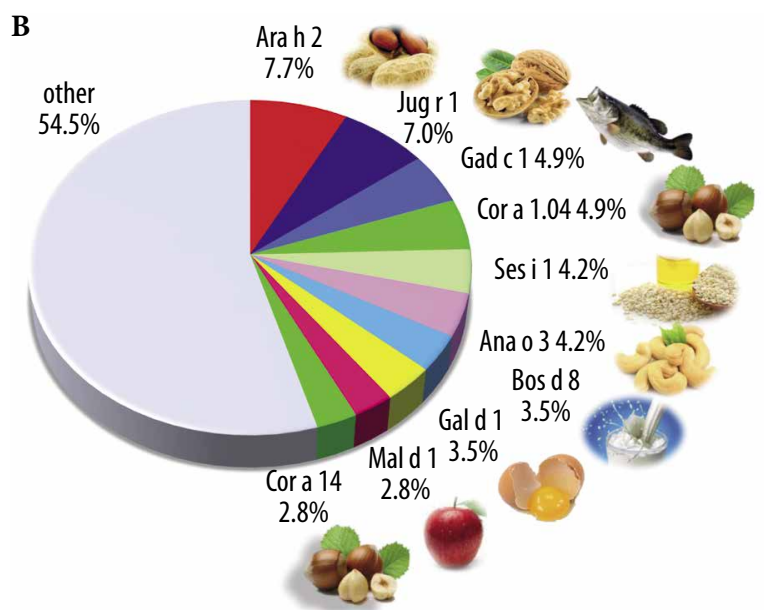

Fig. 5. Aetiology of 143 cases of anaphylaxis in 76 children aged 7-18 years; A. by allergenic sources; B. by allergen molecules (allergens). Own elaboration

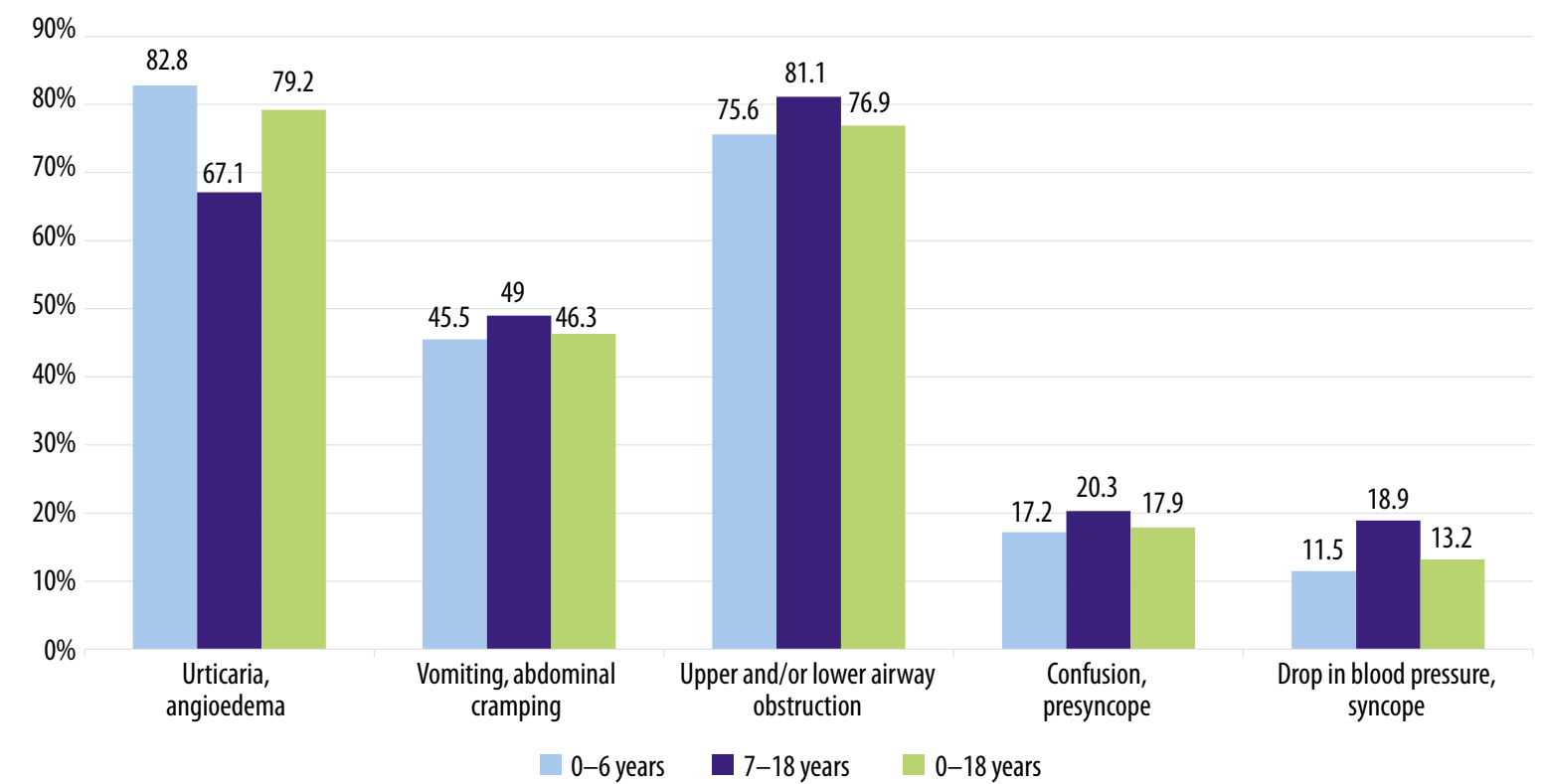

Fig. 6. The incidence of symptoms from different systems in the course of 631 cases of anaphylaxis in children aged 0-18 years, with subdivision into children aged 0-6 (488 reactions) and 7-18 years (143 reactions). Data are presented as percentage values (\%). Own elaboration 
FIA episodes included Bos d 8 (milk casein), Gal d 1 (egg ovomucoid), Ara h 2 (2S peanut albumin), Ses i 1 (2S sesame albumin), Gad c 1 (cod parvalbumin), Ana o 3 (cashew nut $2 \mathrm{~S}$ albumin), Jug $\mathrm{r} 1$ (walnut $2 \mathrm{~S}$ albumin) and Cor a 9 (hazelnut 11S globulin) (Fig. $2 \mathrm{~B}$ ).

The study showed that almost a quarter (23.5\%) of FIA episodes occur in the first year of life, and that the vast majority $(77.3 \%)$ of these episodes develop in the first 6 years of life. Therefore, two age groups were selected for a comparative analysis - children $\leq 6$ years of age and children aged $7-18$ years (Tab. 2$)$. Boys $(p=0.0023)$ and children with AD without asthma $(p=0.0001)$ dominated in the group of children aged 0-6 years, which corresponds to other studies $^{(17,18)}$. Asthma was more common in older children ( $p=0.0128$ ), as in the study by Vetander et al. ${ }^{(16)}$; however, unlike in the cited study, no significantly increased prevalence of any atopic disease was observed in 7-18-year-olds with anaphylaxis. FDEIA diagnosis was many times more common in older children $(p<0.0001)$, the reactions in this age group were characterised by a more severe clinical course $(p=0.0572)$ and adrenaline injection was more common $(p=0.0025)$. These conclusions correspond with both our previous study ${ }^{(9)}$ and other authors ${ }^{(19,20)}$.

From the clinical point of view, the markedly different aetiology of anaphylaxis in both groups, at the level of both allergen sources and allergen molecules, is extremely important (Tabs. 3 and 4, Figs. 4 A, B and 5 A, B). The following allergens dominated in younger children: milk proteins (Bos d 8), egg white ( Gal d 1), peanuts (Ara h 2), sesame (Ses i 1), fish ( Gad c 1) and cashew nuts (Ana o 3). The most common allergens in 7-18-year-olds include peanuts (Ara h 2), hazelnuts (Cor a 9), walnuts (Jug r 1), fish (Gad c 1), sesame (Ses i 1) and cashews (Ana o 3).

The clinical picture of anaphylactic reactions is usually very diverse, with different constellations of the involvement of the individual body systems. Similarly to other authors ${ }^{(19)}$, the most common symptoms in the study population included skin and mucosal involvement (79.2\%); however, these symptoms were significantly less common in older children than in patients under 6 years of age $(67.1 \%$ vs. $82.8 \%$; $p<0.0001)$ (Tab. 5 , Fig. 6$)$. This finding is extremely important from a clinical point of view as it indicates that up to one third of 7-18-year-olds may not present with skin and mucosal symptoms during a food-induced anaphylactic reaction, which poses a risk of delayed diagnosis and treatment of FIA. Although cardiovascular symptoms were the least common (13.2\%), they were significantly more common in older children ( $18.9 \%$ vs. $11.5 \% ; p=0.0247$ ), which probably contributed to a more severe course of FIA in this age group (Tab. 2). The analysis of factors influencing the clinical picture of FIA has yielded significant results, also confirmed in our earlier study ${ }^{(9)}$, which indicate the existence of various clinical phenotypes of food-induced anaphylaxis in children. The risk of severe anaphylaxis was higher in (i) older children ( $p=0.0572)$, (ii) children who did not have asthma or $\operatorname{AD~}(p=0.0428)$, (iii) anaphylaxis to cashew nut $2 \mathrm{~S}$ albumin (Ana o 3), (iv) anaphylaxis to wheat LTP protein (Tri a 14). On the other hand, a significantly milder course of FIA was observed in (i) children with asthma and AD, and (ii) children with anaphylaxis induced by egg white ovomucoid (Gal d 1) (Tabs. 6-8, Figs. 7-9).

The advantages of this study include a collection of several hundred episodes of natural food-induced anaphylactic reactions, which occurred in a large and homogeneous cohort of children aged 1 to 18 years, as well as the prospective nature of the study, allowing for planned and precise collection of medical data and their subsequent analysis. Furthermore, we used the potential of modern molecular diagnosis to identify allergen molecules responsible for

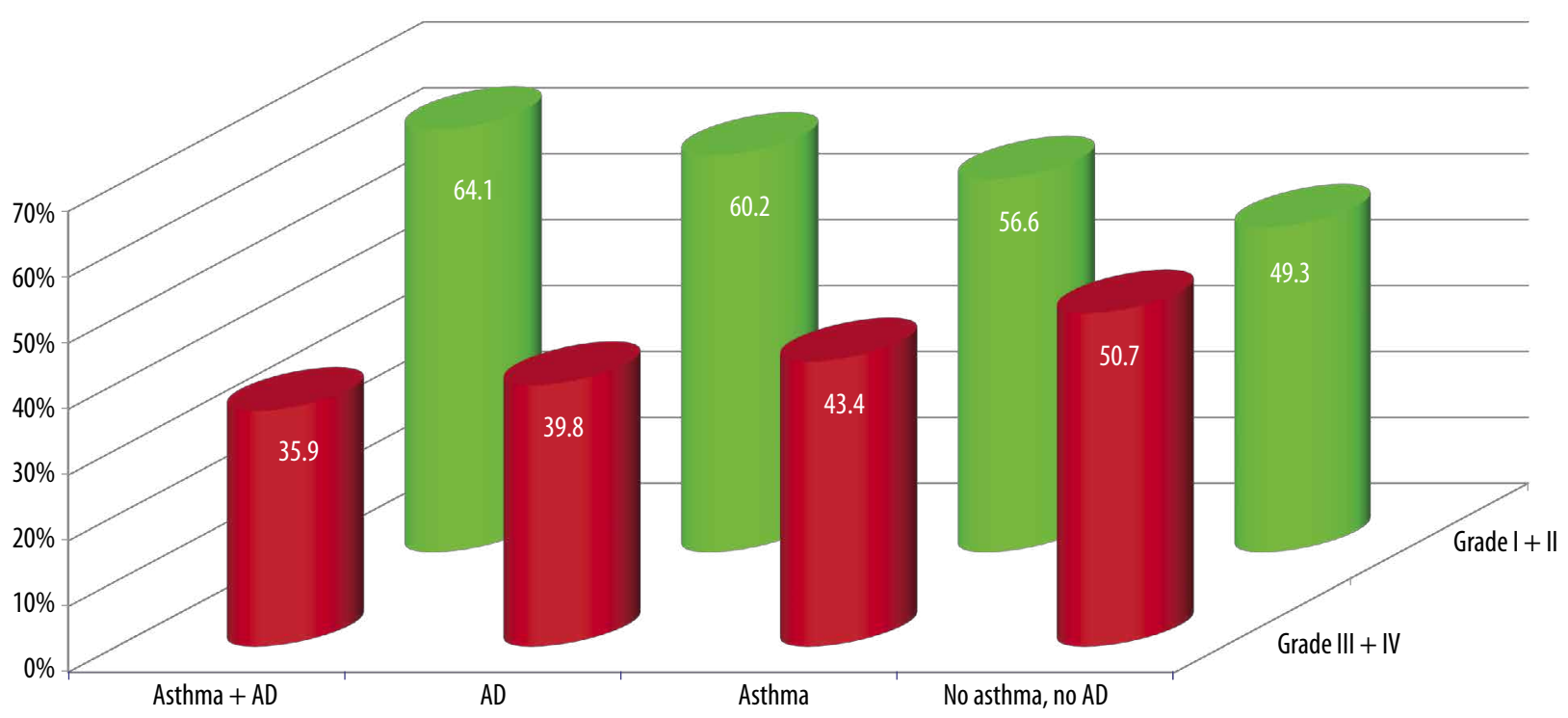

Fig. 7. The incidence of grade 1 and 2 vs. grade 3 and 4 anaphylaxis depending on the coexistence of atopic diseases. Data are presented as percentage values (\%). Own elaboration 


\begin{tabular}{|c|c|c|c|c|}
\hline Diagnosis & $\begin{array}{c}\text { No asthma, } \\
\text { no AD }\end{array}$ & Asthma & AD & AD + asthma \\
\hline $\begin{array}{c}\text { No asthma, } \\
\text { no AD }\end{array}$ & - & 0.334 & 0.1364 & 0.0428 \\
\hline Asthma & 0.3344 & - & 0.5857 & 0.2526 \\
\hline AD & 0.1364 & 0.5857 & - & 0.5295 \\
\hline AD + asthma & 0.0428 & 0.2526 & 0.5295 & - \\
\hline \multicolumn{4}{|l}{ AD - atopic dermatitis. }
\end{tabular}

Tab. 6. Comparison of the severity of the clinical course of anaphylaxis (grade 1 and 2 vs. grade 3 and 4) between groups of patients with different diagnoses. Data are presented using Fisher's exact test probability (p-level) of rejecting the null hypothesis that there are no significant differences. Own elaboration

\begin{tabular}{|c|c|c|c|c|c|}
\hline \multirow{2}{*}{ Source allergen } & \multicolumn{4}{|c|}{$\mathbf{1 + 2}$} & \multicolumn{2}{|c|}{$\mathbf{3 + 4}$} & \multirow{2}{*}{$\boldsymbol{~}$} \\
\cline { 2 - 5 } & $\boldsymbol{n}$ & $\%$ & $\boldsymbol{n}$ & $\%$ & \\
\hline $\begin{array}{c}\text { Cashew nuts } \\
n=26\end{array}$ & 5 & 19.2 & 21 & 80.8 & $<\mathbf{0 . 0 0 0 1}$ \\
\hline $\begin{array}{c}\text { Wheat } \\
n=26\end{array}$ & 13 & 50.0 & 13 & 50.0 & 0.5450 \\
\hline $\begin{array}{c}\text { Peach } \\
n=14\end{array}$ & 7 & 50.0 & 7 & 50.0 & 0.5974 \\
\hline $\begin{array}{c}\text { Peanuts } \\
n=94\end{array}$ & 53 & 56.4 & 41 & 43.6 & 0.9104 \\
\hline $\begin{array}{c}\text { Kiwi } \\
n=17\end{array}$ & 10 & 58.8 & 7 & 41.2 & $>0.9999$ \\
\hline $\begin{array}{c}\text { Cow's milk } \\
n=133\end{array}$ & 80 & 60.2 & 53 & 39.8 & 0.4319 \\
\hline $\begin{array}{c}\text { Fish } \\
n=33\end{array}$ & 20 & 60.6 & 13 & 39.4 & 0.7210 \\
\hline $\begin{array}{c}\text { Apple } \\
n=16\end{array}$ & 10 & 62.5 & 6 & 37.5 & 0.8000 \\
\hline $\begin{array}{c}\text { Walnuts } \\
n=22\end{array}$ & 14 & 63.6 & 8 & 36.4 & 0.6624 \\
\hline $\begin{array}{c}\text { Hazelnuts } \\
n=36\end{array}$ & 23 & 63.9 & 13 & 36.1 & 0.4887 \\
\hline $\begin{array}{c}\text { Sezame } \\
n=34\end{array}$ & 22 & 64.7 & 12 & 35.3 & 0.3793 \\
\hline $\begin{array}{c}\text { Egg white } \\
n=94\end{array}$ & 65 & 69.2 & 29 & 30.8 & $\mathbf{0 . 0 1 2 7}$ \\
\hline
\end{tabular}

Tab. 7. Clinical severity of anaphylaxis by the source allergen inducing symptoms. Comparisons between more severe (grades 3 and 4) and milder (grades 1 and 2) course of anaphylaxis were made using the Fisher's test. Own elaboration

inducing anaphylaxis, which made it possible to identify not only the most common allergens causing FIA, but also, more importantly, allergens posing the highest risk of severe anaphylaxis.

However, our study has also some limitations. Since this was not a population study, it is uncertain whether the results would be similar for a larger population or a different

\begin{tabular}{|c|c|c|c|c|c|}
\hline \multirow{3}{*}{ Allergen } & \multicolumn{4}{|c|}{ Grade } & \multirow{3}{*}{$p$} \\
\hline & \multicolumn{2}{|c|}{$1+2$} & \multicolumn{2}{|c|}{$3+4$} & \\
\hline & $n$ & $\%$ & $n$ & $\%$ & \\
\hline $\begin{array}{l}\text { Ana } 03 \\
n=26\end{array}$ & 5 & 19.2 & 21 & 80.8 & $<0.0001$ \\
\hline $\begin{array}{c}\text { Tri a } 14 \\
n=7\end{array}$ & 2 & 28.6 & 5 & 71.4 & 0.0143 \\
\hline $\begin{array}{l}\text { Cor a } 9 \\
n=15\end{array}$ & 8 & 53.3 & 7 & 46.7 & 0.7966 \\
\hline $\begin{array}{l}\text { Bos d } 8 \\
n=90\end{array}$ & 50 & 55.6 & 40 & 44.4 & 0.8183 \\
\hline $\begin{array}{l}\text { Tri a } 19 \\
n=14\end{array}$ & 8 & 57.1 & 6 & 42.9 & $>0.9999$ \\
\hline $\begin{array}{l}\text { Ara h } 2 \\
n=72\end{array}$ & 43 & 59.7 & 29 & 40.3 & 0.7047 \\
\hline $\begin{array}{l}\text { Gad C1 } \\
n=33\end{array}$ & 20 & 60.6 & 13 & 39.4 & 0.721 \\
\hline $\begin{array}{l}\text { Act d } 1 \\
n=13\end{array}$ & 8 & 61.5 & 5 & 38.5 & 0.786 \\
\hline $\begin{array}{l}\text { Jug } r 1 \\
n=16\end{array}$ & 10 & 62.5 & 6 & 37.5 & 0.8 \\
\hline $\begin{array}{l}\text { Ses i } 1 \\
n=34\end{array}$ & 22 & 64.7 & 12 & 35.3 & 0.3793 \\
\hline $\begin{array}{l}\text { Gal d } 1 \\
n=84\end{array}$ & 59 & 70.2 & 25 & 29.8 & 0.0091 \\
\hline $\begin{array}{l}\text { Mal d } 1 \\
n=14\end{array}$ & 10 & 71.4 & 4 & 28.6 & 0.4138 \\
\hline $\begin{array}{l}\text { Bos d } 4 \\
n=33\end{array}$ & 24 & 72.7 & 9 & 27.3 & 0.0713 \\
\hline $\begin{array}{c}\text { Cor a } 14 \\
n=9\end{array}$ & 7 & 77.8 & 2 & 22.2 & 0.3128 \\
\hline $\begin{array}{c}\text { Cor a } 1 \\
n=8\end{array}$ & 7 & 87.5 & 1 & 12.5 & 0.1469 \\
\hline
\end{tabular}

Tab. 8. Clinical severity of anaphylaxis by symptom-inducing allergen molecule. The comparisons between more severe (grades 3 and 4) and milder (grades 1 and 2) course of anaphylaxis were made using the Fisher's test. Own elaboration

geographic region. We did not rely on the oral food challenge (OFC) in allergy diagnosis as the usefulness and safety of OFC in the diagnosis of anaphylaxis is questioned by many researchers ${ }^{(21-24)}$. Also, the data analysis did not take into account the plasma levels of tryptase as it is not a definitive marker of FIA in children, rarely exceeds the normal range, and its normal value does not exclude the diagnosis of anaphylaxis ${ }^{(25-28)}$.

\section{CONCLUSIONS}

1. Molecular diagnostic methods in allergology allow for the precise determination of the allergen responsible for food-induced anaphylaxis at the level of an allergenic molecule, which in turn makes it possible to assess the 


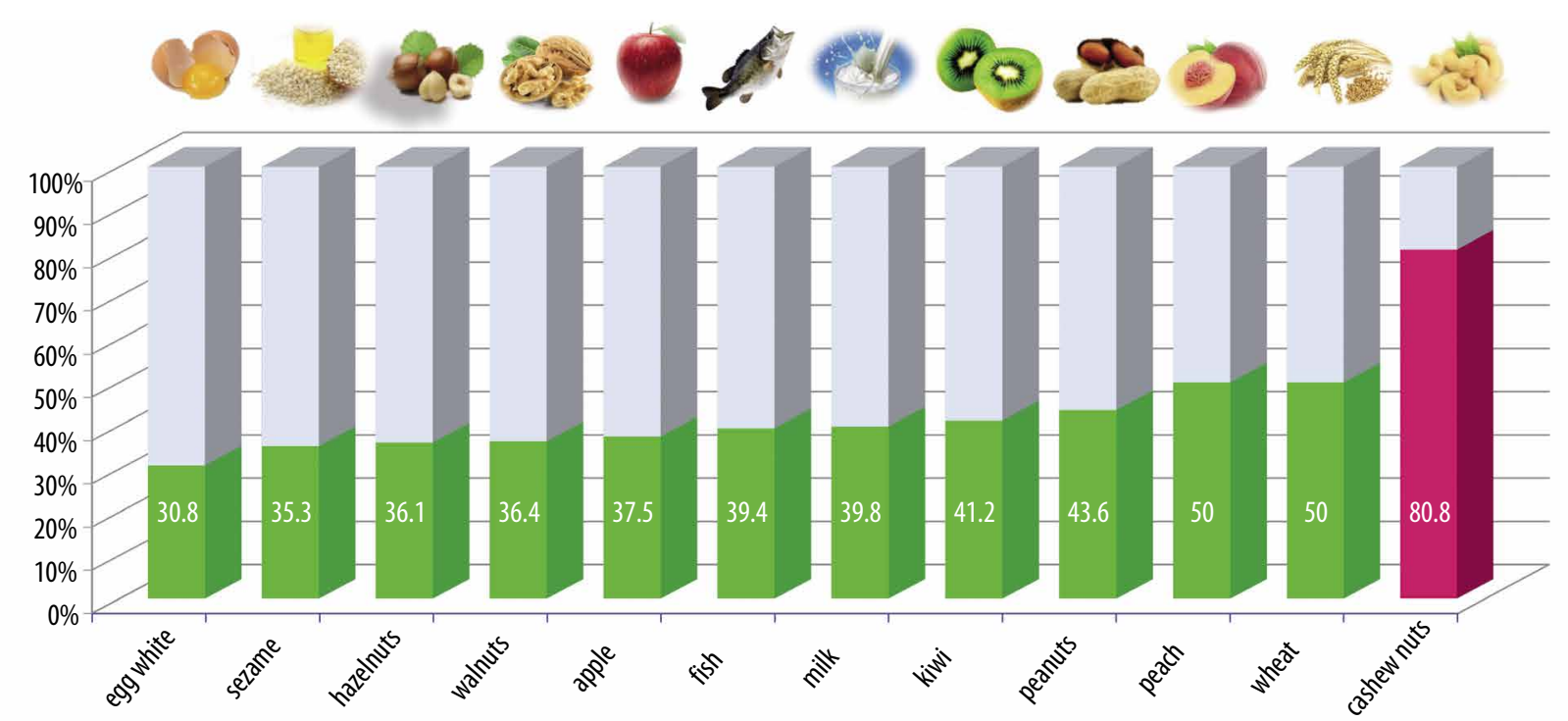

Fig. 8. The incidence of grade 3 and 4 reactions depending on the allergenic source causing anaphylaxis. Data are presented as percentage values (\%). Own elaboration

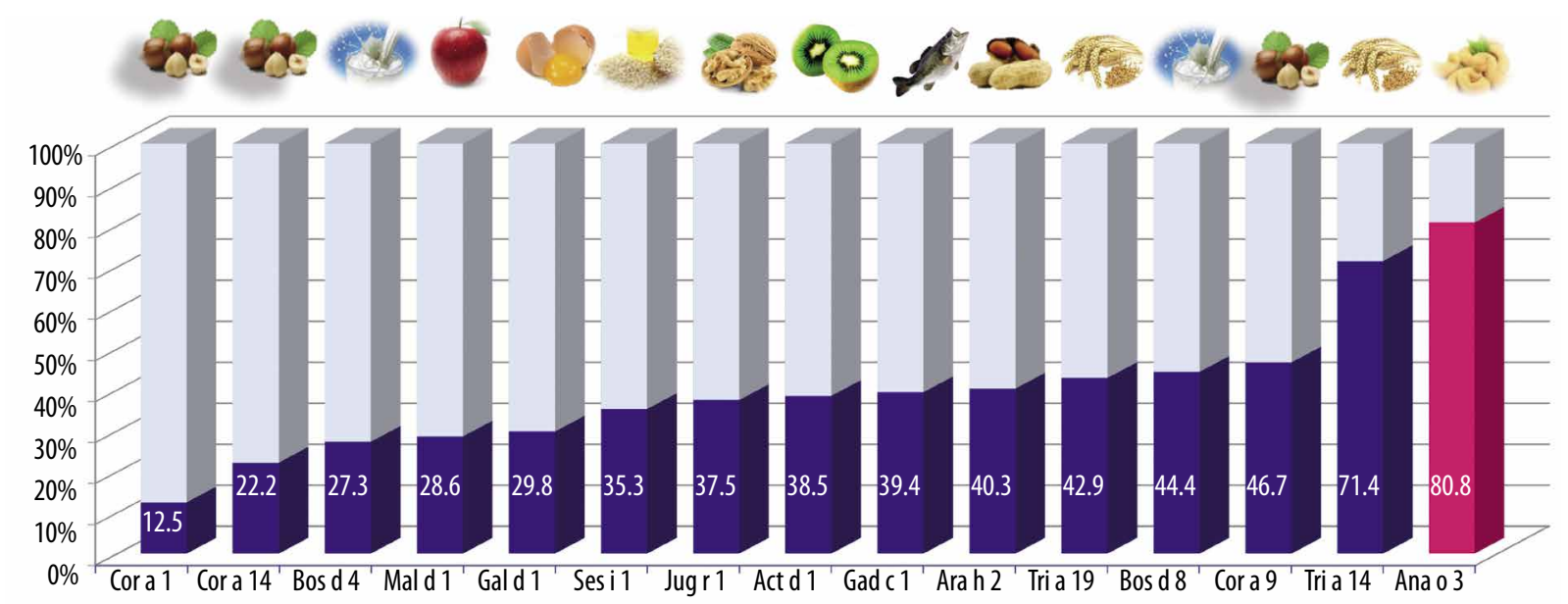

Fig. 9. The incidence of grade 3 and 4 reactions depending on the allergenic molecule causing anaphylaxis. Data are presented as percentage values (\%). Own elaboration

risk of severe anaphylaxis depending on the allergy to a specific molecule.

2. The epidemiology and the nature of the clinical course of FIA in infants and preschool children are significantly different than those seen in school-age children and adolescents.

3. Demographic parameters, the clinical course of reaction and the molecular picture of the allergen make it possible to determine various clinical phenotypes of food-induced anaphylaxis in children.

\section{Conflict of interest}

The authors do not report any financial or personal connections with other persons or organisations, which might negatively affect the contents of this publication and/or claim authorship rights to this publication.

\section{Acknowledgements}

We would like to thank the entire team of the Allergology and Pulmonology Department, Institute of Tuberculosis and Lung Diseases, Regional Branch in Rabka-Zdrój, especially Elżbieta Mazurek, Iwona Sak, Beata Gabis, Katarzyna Gregorczyk-Maślanka, Anna Czyżewska-Dudek, Jadwiga Biela-Mazur, Karolina Miśkiewicz, Marcin Baut and Adam Wójcik, for cooperation and assistance in the processing of medical data. 


\section{References}

1. Venter C, Patil V, Grundy J et al.: Prevalence and cumulative incidence of food hypersensitivity in the first 10 years of life. Pediatr Allergy Immunol 2016; 27: 452-458.

2. Turner PJ, Worm M, Ansotegui IJ et al. and WAO Anaphylaxis Committee: Time to revisit the definition and clinical criteria for anaphylaxis? World Allergy Organ J 2019; 12: 100066.

3. Błażowski $€$, Kurzawa R: Odrębności anafilaksji u niemowląt i małych dzieci. In: Kruszewski J (ed.): Analiza przypadków klinicznych $\mathrm{w}$ alergologii. Leczenie farmakologiczne $\mathrm{w}$ praktyce polskich lekarzy. Część II. PZWL, Warszawa 2018: 71-84.

4. Ansotegui IJ, Melioli G, Canonica GW et al.: A WAO-ARIA-GA²LEN consensus document on molecular-based allergy diagnosis (PAMD@): update 2020. World Allergy Organ J 2020; 13: 100091.

5. Sampson HA, Muňoz-Furlong A, Campbell RL et al.: Second symposium on the definition and management of anaphylaxis: summary report - Second National Institute of Allergy and Infectious Disease/Food Allergy and Anaphylaxis Network symposium. J Allergy Clin Immunol 2006; 117: 391-397.

6. Australasian Society of Clinical Immunology and Allergy (ASCIA): Acute Management of Anaphylaxis. Available from: https://www.allergy.org.au/images/ASCIA_HP_Guidelines_ Acute_Management_Anaphylaxis_2020.pdf [cited: 15 May 2020].

7. Mueller HL: Diagnosis and treatment of insect sting sensitivity. J Asthma Res 1966; 3: 331-333.

8. Heinzerling L, Mari A, Bergmann KC et al.: The skin prick test European standards. Clin Transl Allergy 2013; 3: 3.

9. Blazowski L, Majak P, Kurzawa R et al.: Food allergy endotype with high risk of severe anaphylaxis in children - monosensitization to cashew 2 S albumin Ana o 3. Allergy 2019; 74: 1945-1955.

10. Cox LS, Sanchez-Borges M, Lockey RF: World Allergy Organization systemic allergic reaction grading system: is a modification needed? J Allergy Clin Immunol Pract 2017; 5: 58-62.e5.

11. Global Initiative for Asthma: Global Strategy for Asthma Management and Prevention. Updated 2020. Available from: https://ginasthma.org/reports/ [cited: 15 May 2020].

12. Kunz B, Oranje AP, Labrèze $L$ et al.: Clinical validation and guidelines for the SCORAD index: consensus report of the European Task Force on Atopic Dermatitis. Dermatology 1997; 195: 10-19.

13. Jahnz-Rozyk K, Raciborski F, Śliwczyński M et al.: Anaphylaxis in Poland: the epidemiology and direct costs. Postepy Dermatol Alergol 2017; 34: 573-579.

14. Miles BT, Gabrielli S, Clarke A et al.: Rates of anaphylaxis for the most common food allergies. J Allergy Clin Immunol Pract 2020; 8: 2402-2405.e3.
15. Fernandes RA, Regateiro F, Pereira $C$ et al.: Anaphylaxis in a food allergy outpatient department: one-year review. Eur Ann Allergy Clin Immunol 2018; 50: 81-88.

16. Vetander M, Protudjer JLP, Lilja G et al.: Anaphylaxis to foods in a population of adolescents: incidence, characteristics and associated risks. Clin Exp Allergy 2016; 46: 1575-1587.

17. Ramsey NB, Guffey D, Anagnostou K et al.: Epidemiology of anaphylaxis in critically ill children in the United States and Canada. J Allergy Clin Immunol Pract 2019; 7: 2241-2249.

18. Pouessel G, Jean-Bart C, Deschildre A et al.; Allergy Vigilance Network: Food-induced anaphylaxis in infancy compared to preschool age: a retrospective analysis. Clin Exp Allergy 2020; 50: 74-81.

19. Grabenhenrich LB, Dölle S, Moneret-Vautrin A et al.: Anaphylaxis in children and adolescents: the European Anaphylaxis Registry. J Allergy Clin Immunol 2016; 137: 1128-1137.

20. Worm M, Francuzik W, Renaudin JM et al.: Factors increasing the risk for a severe reaction in anaphylaxis: an analysis of data from the European Anaphylaxis Registry. Allergy 2018; 73: 1322-1330.

21. Turner PJ, Baumert JL, Beyer K et al.: Can we identify patients at risk of life-threatening allergic reactions to food? Allergy 2016; 71: 1241-1255.

22. Turner PJ, Wainstein BK: Crossing the threshold: can outcome data from food challenges be used to predict risk of anaphylaxis in the community? Allergy 2017; 72: 9-12.

23. Wainstein BK, Studdert J, Ziegler M et al.: Prediction of anaphylaxis during peanut food challenge: usefulness of the peanut skin prick test (SPT) and specific IgE level. Pediatr Allergy Immunol 2010; 21: 603-611.

24. Grabenhenrich LB, Reich A, McBride D et al.: Physician's appraisal vs documented signs and symptoms in the interpretation of food challenge tests: the EuroPrevall birth cohort. Pediatr Allergy Immunol 2018; 29: 58-65.

25. Simons FER, Ardusso LR, Bilò MB et al.: International consensus on (ICON) anaphylaxis. World Allergy Organ J 2014; 7: 9.

26. Lieberman JA, Bingemann TA, Wang J: Diagnostic challenges in anaphylaxis. J Allergy Clin Immunol Pract 2020; 8: 1177-1184.

27. De Schryver S, Halbrich M, Clarke A et al.: Tryptase levels in children presenting with anaphylaxis: temporal trends and associated factors. J Allergy Clin Immunol 2016; 137: 1138-1142.

28. Platzgummer S, Bizzaro N, Bilò MB et al.: Recommendations for the use of tryptase in the diagnosis of anaphylaxis and clonal mastcell disorders. Eur Ann Allergy Clin Immunol 2020; 52: 51-61. 